\title{
RANCANGAN SEDERHANA PENENTUAN MODULUS PUNTIR BATANG BESI UNTUK PEMBELAJARAN PESERTA DIDIK
}

\author{
Thoha Firdaus \\ Program Studi Pendidikan Fisika, STKIP Nurul Huda \\ Jalan Kotabaru Sukaraja, Buay Madang, OKU Timur, Sumatera Selatan \\ E-mail: thohaf@stkipnurulhuda.ac.id
}

\begin{abstract}
Abstrak
Modulus puntir merupakan materi yang asing di kalangan pelajar, mereka lebih akrab dengan materi modulus Young Ini dikarenakan sulitnya seorang guru menjelaskan fenomena dan eksperimen yang pasti tentang materi ini. Percobaan sederhana penentuan modulus puntir batang besi telah dilakukan dengan menggunakan metode pelengkungan. Metode yang digunakan adalah dengan analisis regresi linier tanpa bobot hubungan antara sudut puntir dengan massa beban tambahan, dan pengambilan data untuk penentuan nilai modulus puntir batang besi dilakukan dengan variasi massa beban. Setiap variasi massa, sudut yang terbentuk diukur menggunakan busur derajat sebanyak 7 kali. Koefisien modulus puntir dapat dihitung dari gradien garis hasil regresi antara sudut puntir dengan massa beban tambahan. Setelah dilakukan regresi dari 7 data eksperimen, diperoleh nilai koefisien modulus puntir batang besi sebesar $G=(0,055 \pm 0,007) \times 10^{12} \mathrm{~Pa}$, nilai ini tidak jauh berbeda dengan perkiraan nilai modulus puntir pada bahanbahan yang sejenis lainnya.
\end{abstract}

Kata kunci: modulus puntir, besi, metode pelengkungan.

\section{PENDAHULUAN}

Modulus tidak asing dalam pokok bahasan fisika, terutama modulus Young yang cukup sudah akrab dalam pembahasan materi elastisitas pada mata pelajaran fisika SMA. Tetapi modulus Puntir cukup asing ditelinga mereka, padahal pembahasan modulus puntir sangat penting untuk diajarkan kepada mereka. Selain itu, pembahasan modulus puntir terkadang sulit bagi guru untuk memberikan pengajaran dan praktikum, sehingga dengan adanya penelitian ini diharapkan pembaca yang berprofesi sebagai tenaga pengajar dapat menjadikan penelitian ini sebagai acuan dan tambahan informasi. Selain itu ketepatan memilih media pembelajaran merupakan faktor utama dalam mengoptimalkan hasil pembelajaran. Untuk memilih media yang tepat seorang pendidik perlu mempertimbangkan berbagai landasan agar media yang dipilih benar-benar sesuai dengan tingkat pemahaman kemampuan berfikir, psikologis, dan kondisi sosial siswa (Firdaus, 2015).
Berkenaan dengan modulus puntir, maka pembahasan diawali dengan adanya torsi. Torsi adalah suatu pemuntiran sebuah batang yang diakibatkan oleh kopel-kopel yang menghasilkan perputaran terhadap sumbu longitudinalnya. Kopel-kopel yang menghasilkan pemuntiran sebuah batang disebut momen putar atau momen puntir. Momen $(\tau)$ sebuah kopel sama dengan hasil kali salah satu gaya $(\vec{F})$ dari pasangan gaya ini dengan jarak antara garis $(d)$ kerja dari masing-masing gaya. Penjelasan ini di ilustrasikan seperti pada gambar 1 dan persamaan 1.

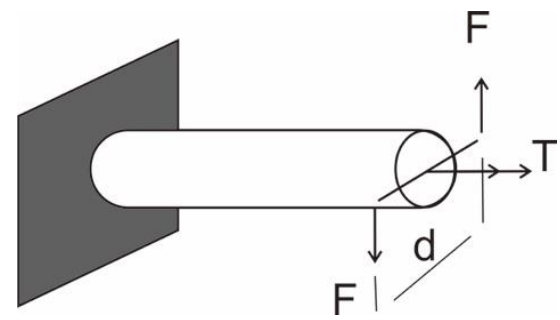

Gambar 1. Sistem gaya terhadap torsi

$$
\tau=F d
$$


Penelitian sebelumnya telah dilakukan oleh beberapa peneliti, diantanya adalah Spektafest (2013) dengan menggunakan batang logam didapatkan hasil modulus puntirnya adalah $G=0,0625 \times 10^{12} \mathrm{~Pa}$ analisis yang digunakan dalam penelitian ini yakni dengan regresi linier tanpa bobot. Dilakukan pula penelitian oleh Jonatan (2010), yang menggunakan batang baja dengan mendapatkan nilai modulus puntir sebesar $\mathrm{G}=0,0365 \times 10^{12} \mathrm{~Pa}$, analisis yang digunakan dengan perhitungan rata-rata. Mulya (2010) juga melakukan penelitian menentukan nilai modulus puntir pada batang kayu didapat nilai $G=62,25 \times 10^{12} \mathrm{~Pa}$, dengan menvariasai panjang batang maka sistem pengambilan data ini juga dengan rata-rata hasil data. Penelitian selanjutnya dilakukan oleh Prabowo (2013) dengan didapat nilai modulus puntir $G=$ 4647,05 MPa/rad.

Dari banyak penelitian yang dilakukan, belum ditemukan penelitian modulus puntir dengan menggunakan batang besi. Penelitian selanjutnya yang akan di teliti kali ini akan memberikan tambahan informasi mengenai hasil modulis puntir khususnya menggunakan batang besi.

\section{METODE/EKSPERIMEN}

\section{A. Alat dan Bahan}

Alat dan bahan yang digunakan dalam penelitian ini yang paling utama adalah batang silinder besi, yaitu sebagai subjek penelitian. Selanjutnya ada alat ukur panjang untuk mengukur panjang batang besi, 7 buah beban untuk digunakan sebagai perubahan data varian, mikrometer sekrup untuk mengukur diameter batang besi, jarum penunjuk sebagai alat bantu penunjuk arah derajat, dan busur sebagai alat ukur informasi. Rangkaian alat percobaan yang di susun dapat diilustrasikan seperti pada gambar 2 .

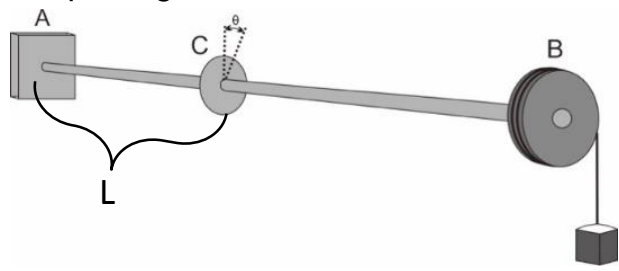

Gambar 2. Skema sistem kerja

\section{B. Prosedur Percobaan}

Diameter batang besi dan roda pemutar diukur menggunakan mikrometer sekrup besi dengan ketelitian $0,025 \mathrm{~cm}$. Kemudian memasukkan satu ujung batang ke dalam penjepit diam dan ujung yang lain ke dalam panjepit pemuntir. Setelah itu memasang jarum pengamat pada jarak tertentu dari penjepit diam. Dan untuk percobaannya dengan cara membebani roda pemutar dengan dasar beban yang bervariasi. Jarum penunjuk skala pada posisi $90^{\circ}$ diletekkan dekat dengan busur terjadi pemutaran sudut yang bervariasi sesuai variasi beban benda.

\section{HASIL DAN PEMBAHASAN}

Diawali dengan menggunakan persamaan (1), melalui beberapa penurunan rumus dengan melibatkan teganan geser $(\sigma)$, hubungan jarak $(L)$, jari-jari $(R)$, massa $(M)$, dan sudut $(\theta)$, maka didapatkan persamaan modulus puntir berikut:

$$
G=\frac{2 L m g r}{\pi \theta \cdot R^{4}}
$$

Sedangkan rangkaian yang telah di buat dapat dilihat pada gambar (3).

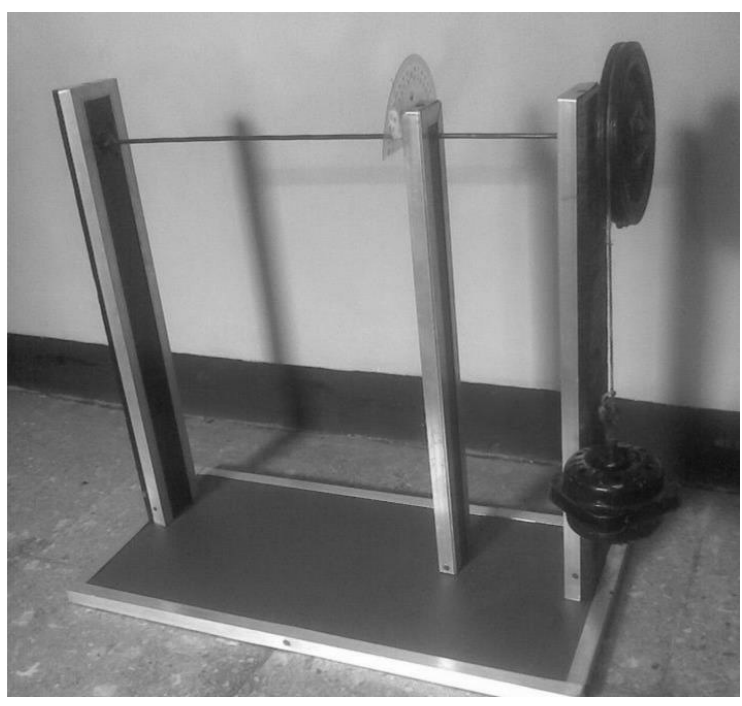

Gambar 3. Rancangan penelitian

\section{A. Hasil Penelitian}

Diketahui data awal adalah: $\pi=\pi=3,14$; $R=2,2 \times 10^{-3} \mathrm{~m} ; L=0,255 \mathrm{~m} ; r=63 \times 10^{-3} \mathrm{~m} ; g=9,8$ $\mathrm{m} / \mathrm{s}^{2}$. 


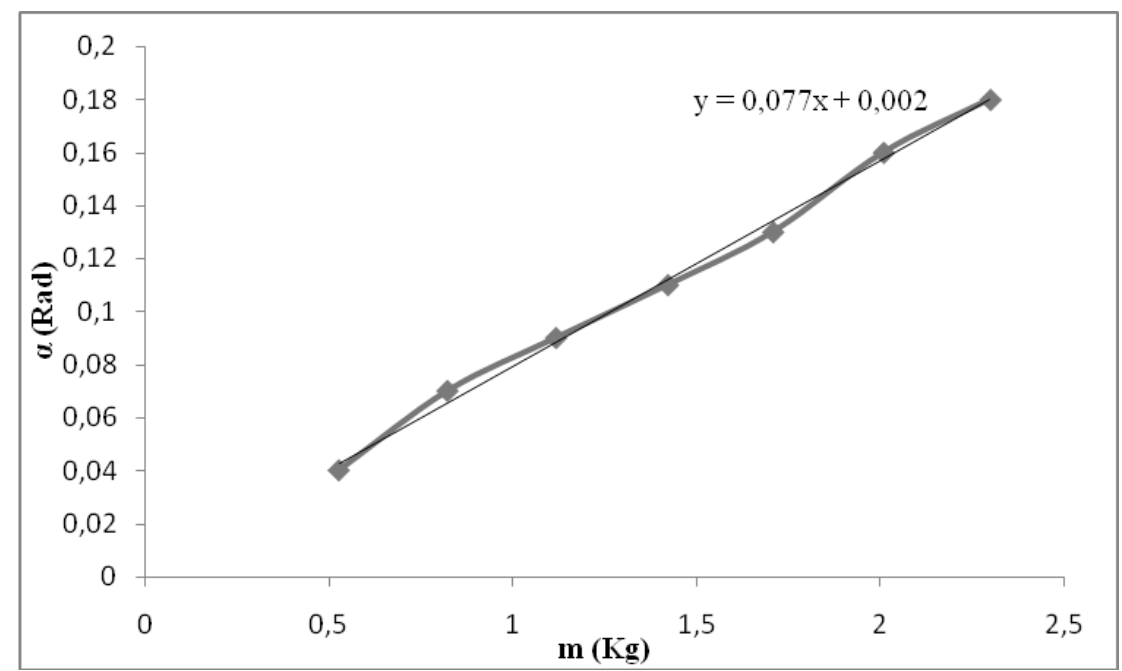

Gambar 4. Grafik basil percobaan hubungan massa dan sudut

Sedangkan penambahan sudut terhadap penambahan massa beban didapat hasil tabel 1.

Tabel 1. Data percoaan

\begin{tabular}{ccc}
\hline No & $m(\mathrm{Kg})$ & $\alpha(\mathrm{Rad})$ \\
\hline 1 & 0,527 & 0,04 \\
2 & 0,822 & 0,07 \\
3 & 1,117 & 0,09 \\
4 & 1,421 & 0,11 \\
5 & 1,707 & 0,13 \\
6 & 2,007 & 0,16 \\
7 & 2,297 & 0,18 \\
\hline
\end{tabular}

Data pada tabel 1 menunjukkan semakin besar beban yang digantungkan maka sudut yang didapat akan semakin besar juga, dari sini dapat dilihat bahwa data tersebut memenuhi persamaan linier

\section{B. Pembahasan}

Berdasarkan data percobaan yang telah dilakukan, maka didapatkan skema grafik hubungan antara masa dan sudut yang dibentuk seperti gambar 4 .

Karena peneliti menggunakan analisis linear tanpa bobot, maka persamaan (2) dapat dimisalkan

$$
\theta=\frac{2 L r g}{G \pi R^{4}} m .
$$

Karena yang berubah sudut terhadap massa, maka mengikuti persamaan garis linier:

$$
y=a x+b
$$

dengan $\theta$ sebagai $y$ dan $m$ sebagai $x$ maka diperoleh nilai adalah

$$
a=\frac{2 \operatorname{Lrg}}{G \pi R^{4}} \text {. }
$$

Sehingga ketetapan modulus puntir dengan menggunakan regresi linier didapat rumus:

$$
G=\frac{2 L r g}{a \pi R^{4}},
$$

Dari hasil grafik linier gambar 4 maka didapatkan persamaan linier dengan $a=0,077$ dan $b=0,002$. Dengan mengikuti persamaan 5 dan 6 , maka didapatkan nilai modulus puntir dengan $G=(0,055 \pm 0,007) \times 10^{12} \mathrm{~Pa}$.

\section{PENUTUP}

Ditinjau dari hasil dan pembahasan diatas, maka dapat diambil sebuah kesimpulan bahwa nilai modulus puntir pada batang besi didapat $G=(0,055 \pm 0,007) \times 10^{12} \mathrm{~Pa}$. Seorang tenaga pendidik juga dapat menjadikan eksperimen sederhana dan nilai ketetapan modulus puntir batang besi ini sebagai informasi tambahan yang dapat di tunjukkan kepada peserta didiknya.

\section{UCAPAN TERIMAKASIH}

Terimakasih saya ucapkan kepada dosen-dosen peneliti yang ikut kontribusi dalam menyumbangkan ilmunya, di antaranya dosen Universitas Ahmad Dahlan. Kemudian 
terimakasih saya ucapkan kepada STKIP Nurul Huda yang memberikan kesempakan untuk menerbitkan hasil penelitian ini di journal resminya.

\section{DAFTAR PUSTAKA}

Anonim. Kuliah Online Kekuatan Bahan. Diambil dari:

http://web.ipb.ac.id/ lbp/kulon/diktat/8.p df.

Firdaus, T. (2016). Pengembangan Media Pembelajaran Arus dan Tegangan Listrik Bolak-Balik untuk SMA/MA Kelas XII Menggunakan Program Spreadsheet. Jurnal Inovasi Dan Pembelajaran Fisika, 2(2), 197-203.

Jonatan dkk. (2010). Modul C Uji Puntir. Laboratorimu Metalurgi Fakultas Teknik Mesin dan Diargantara ITB.

Kristiyanto R. Dkk. (2010). Praktikum Fisika Dasar M-10 Modulus Puntir. Teknik Industri FakultasTeknologi Industri UMB.

Mulya, R. (2010). Praktikum Fisika Industri Modulus Puntir. Teknik Industri Mercu Buana.

Prabowo, D.A. dkk. (2013). Modul C Uji Puntir. Laboratorimu Metalurgi Fakultas Teknik Mesin dan Diargantara ITB.

Spektafest, GGM. (2013). Laporan Modulus Puntir (M4). Laporan Praktikum Fisika Dasar 1 ITENAS Bandung 